\title{
Studies on the Antibacterial Activity of Ceftiofur Sodium in Vitro and Birds
}

\author{
Khalid A. Al-Kheraije \\ Shaqra University, Shaqra, KSA \\ Email: dr.khalidalkheraije@yahoo.com
}

Received December 2, 2012; revised January 4, 2013; accepted February 5, 2013

\begin{abstract}
This study was carried out to evaluate the antibacterial activity of ceftiofur sodium as anti-infective chemotherapeutic agent belonged to the third generation of cephalosporins against different bacterial pathogens in vitro and birds. The obtained results showed that it was more effective and superior in its action than that the other compared antibacterial agents. The disc diffusion test revealed that most $P$. multocida isolates were highly sensitive to ceftiofur sodium with minimum inhibitory concentrations (MICs) ranging between $0.625-2.5 \mu \mathrm{g} / \mathrm{ml}$ and minimal bactericidal concentration (MBCs) equal or two folds of the MICs.
\end{abstract}

Keywords: Ceftiofur Sodium (Excenel); Microorganisms; Minimum Inhibitory Concentration (MICs); Minimum Bactericidal Concentration (MBCs); Chemotherapeutic; Birds

\section{Introduction}

Ceftiofur sodium (Excenel) is a newly introduced chemotherapeutic agent for use in veterinary practice [1] not only for large and small animals but also for poultry and fishes against Gram-positive and Gram-negative bacteria $[2,3]$. The resistance of some bacterial pathogens to existing antimicrobial is wide spread, so continuous research for new drugs for controlling the diseases are necessary. Ceftiofur sodium (Excenel) is one of the third generation cephalosporins. It is a broad spectrum antibiotic active against both Gram-positive and Gram-negative bacteria, including $\beta$-lactamase producing strains. It is bactericidal; destroying bacteria by preventing the synthesis of the cell wall $[4,5]$. It is used for treatment of respiratory tract diseases in cattle, sheep, horse and swine that are caused by P. multocida and P. haemolytica [610]. It was reported for the control of $P$. multocida infection in balady chickens [2], and also for the control of terminal bacterial infection in one day old broiler chickens [11], and American black ducks [12]. The effect of therapeuticceftiofur administration to dairy cattle on $E$. coli was studied [13]. This study was planned as an attempt to evaluate the antibacterial activity of ceftiofur sodium (Excenel) against different bacterial pathogens both in vitro and in vivo (in birds, in comparison with commonly used antibacterial agents.

\section{Meterials and Methods}

\subsection{Tested Organisms}

Forty strains of $E$. coli, 32 strains of $S$. aureus, 5 strains of
Pseudomonas aerugonosa, 15 isolates of Salmonella spp., 12 isolates of Proteus spp., 10 isolates of Pasteurella multocida besides 3 isolates of $C$. ovis were used to check their succeptibility against different antibacterial drugs.

\subsection{Antibacterial Agents Used}

Ceftiofur sodium (Excenel), enrofloxacin (Uvetril), flumequine, gentamicin, neomycin, streptomycin and ampicillin. Discs of Whattman filter papers were done and soaked intoexcenel solution in water [14]. Each disc contained $1 \mu \mathrm{g}$ while discs of uvetril, Flumequine, gentamicin, neomycin, streptomycin and ampicillin were supplied from BioMerieux Co., France. A disc diffusion technique of antibiotics sensitivity testing was done [14-17].

\subsection{Determination of Antimicrobial Agents}

The antimicrobial agents used for determination of MICs were Ceftiofur sodium (Excenel Upjohn Company USA), Enrofloxacin 10\% (Amoun Egypt), Flumequine (Amoun Egypt), gentamicin $10 \%$, Neomycin, Streptomycin and Ampicillin (EL-Naser Company). The tube dilution method for determination of minimal inhibitory concentration (MICs) and minimal bactericidal concentration (MBCs) were done for P. multocida (as representative bacterial isolates) according to a reported method [18].

\subsection{Experimental Design}

Seventy Hubbard chicks of 20 days old with average 200 gm body weight were divided into three groups each of 
20 chicks and 10 of them were left as a control. First group received Salmonella gallinarum with an intraperitoneal inoculation of infective dose $6 \times 10^{4}$ viable cells [16-19]. Chicks of second group succumbed to an artificial infection with $P$. multocida with an intramuscular dose of $1 \times 10^{4}$ viable cells $/ \mathrm{ml}[10,20]$, while each chick of third group was intravenously inoculated with $0.1 \mathrm{ml}$ of broth culture of $E$. coli containing $10^{8}$ viable cells $/ \mathrm{ml}$ [21]. All inoculated and control birds were daily observed and reared under strict hygienic measures. When the characteristic signs of the induced disease appeared, each inoculated bird received an intramuscular injection of ceftiofur sodium (excenel) dissolved in sterile distilled water with a dose of $1 \mathrm{mg} / \mathrm{kg}$ of body weight (1 ml of reconstituted sterile solution of excenel per $50 \mathrm{~kg}$. of body weight) as it was recommended by manufacture (Pharmacia and Upjohn, Animal health, Kalamazoo, MI 49001 USA) in a trial to evaluate its action to relieve the symptoms of such avian pathogens.

Two flocks of fattening Hubbard breed chicks each of 5000 birds bred in two floor farms (lower and upper floors, private farm, Sharkia Governorate) were used to make field application of excenel treatment. The birds of first flock received twice application; the first one was daily administration for the first three days of life with a dose $1 \mathrm{mg}$ Excenel $/ \mathrm{kg}$ B.wt. via drinking water $(1 \mathrm{ml}$ of Excenel solution per $50 \mathrm{~kg}$ B.wt.); while the second application was done at 30 days of their life with a same dose. The birds of the second flock received no Excenel but their treatment program depended on other antibiotics rather than excenel and served as control. The birds of both flocks received fattening balanced ration contained coxistac as anticoccidial agent for 45 days and were routinely vaccinated against I.B.D. and Newcastle disease.
The mortality rate, general health condition and food conversion rate were the parameters of comparison between the birds of both flocks.

Statistical analysis of results were carried out according to a reported method [22].

\section{Results}

\subsection{Results of in Vitro Antibiotics Sensitivity Test}

It revealed that 39 out of 40 tested strains of $E$. coli were sensitive to ceftiofur sodium with an activity of $97.5 \%$, 30 strains of $S$. aureus were also sensitive with activity percentage of $93.75 \%$, for $P$ s. aeruginosa the activity percentage of $80 \%$ was recorded to ceftiofur sodium as 4 strain were sensitive from the five tested isolates, 13 isolates of Salmonella species were sensitive to Excenel discs with activity of $86.7 \%$, all tested isolates of Proteusspecies were completely sensitive (100\%), 9 strains belonged to $P$. multocida were sensitive with activity of $90 \%$ and all tested strains of $C$. ovis were completely sensitive to ceftiofur sodium (100\%), such superior action of ceftiofur sodium disc was compared with the action of other antibiotic discs in vitro on the same tested microorganisms as it was tabulated in Table 1.

\subsection{Tube Dilution Method for Determination of MICs and MBCs for P. multocida Strains}

The means zones of inhibition, MICs and MBCs for ceftiofur sodium and other antimicrobial agents against $P$. multocida strains are shown in Table 2. Most of P. multocida strains showed a high degree of sensitivity to ceftiofur. Fifty percent of tested strains were inhibited by

Table 1. Results of antibiotics sensitivity testing against ceftiofur sodium compared with commonly used antibiotics in vitro.

\begin{tabular}{|c|c|c|c|c|c|c|c|c|c|c|c|c|c|c|c|}
\hline \multirow{2}{*}{$\begin{array}{l}\text { Chemotherapeutic } \\
\text { disc disc }\end{array}$} & \multirow{2}{*}{ Potency } & \multicolumn{2}{|c|}{$\begin{array}{l}\text { E. coli } \\
(40)\end{array}$} & \multicolumn{2}{|c|}{$\begin{array}{l}\text { S. aureus } \\
\text { (32) }\end{array}$} & \multicolumn{2}{|c|}{$\begin{array}{l}\text { Ps. aeruginosa } \\
\text { (5) }\end{array}$} & \multicolumn{2}{|c|}{$\begin{array}{c}\text { Salmonella spp. } \\
\text { (15) }\end{array}$} & \multicolumn{2}{|c|}{$\begin{array}{l}\text { Proteus spp. } \\
\quad(12)\end{array}$} & \multicolumn{2}{|c|}{$\begin{array}{l}\text { P. multocida } \\
(10)\end{array}$} & \multicolumn{2}{|c|}{$\begin{array}{l}\text { C. ovis } \\
\text { (3) }\end{array}$} \\
\hline & & $\mathrm{a}$ & $\mathrm{b}$ & $\mathrm{a}$ & $\mathrm{b}$ & $\mathrm{a}$ & B & $\mathrm{a}$ & $\mathrm{b}$ & $\mathrm{a}$ & $\mathrm{b}$ & $\mathrm{a}$ & $\mathrm{b}$ & $\mathrm{a}$ & $\mathrm{b}$ \\
\hline $\begin{array}{l}\text { Ceftiofur sodium } \\
\text { (Excenel) }\end{array}$ & $1 \mu \mathrm{g}$ & 39 & 97.5 & 30 & 93.75 & 4 & 80.0 & 13 & 86.7 & 12 & 100.0 & 9 & 90.0 & 3 & 100.0 \\
\hline Enrofloxacin & $5 \mu \mathrm{g}$ & 37 & 92.7 & 28 & 87.5 & 3 & 60.0 & 12 & 80.0 & 11 & 91.7 & 8 & 80.0 & 2 & 66.7 \\
\hline Flumequine & $30 \mu \mathrm{g}$ & 28 & 70.0 & 15 & 46.88 & 3 & 60.0 & 11 & 73.3 & 10 & 83.3 & 4 & 40.0 & 2 & 66.7 \\
\hline Gentamicin & $10 \mu \mathrm{g}$ & 27 & 67.5 & 25 & 78.13 & 3 & 60.0 & 10 & 66.7 & 9 & 75.0 & 6 & 60.0 & 2 & 66.7 \\
\hline Neomycin & $30 \mu \mathrm{g}$ & 21 & 27.5 & 17 & 53.13 & 1 & 20.0 & 8 & 53.3 & 5 & 41.7 & 2 & 20.0 & 1 & 33.3 \\
\hline Streptomycin & $10 \mu \mathrm{g}$ & 12 & 30.0 & 10 & 31.3 & 0 & 00.0 & 5 & 33.3 & 3 & 25.0 & 1 & 10.0 & 0 & 00.0 \\
\hline Ampicillin & $10 \mu \mathrm{g}$ & 16 & 40.0 & 9 & 28.13 & 1 & 20.0 & 6 & 40.0 & 2 & 16.7 & 1 & 10.0 & 0 & 00.0 \\
\hline $\mathrm{R}$ & & & $\mathrm{R}$ & & $\mathrm{R}$ & & $\mathrm{R}$ & & $\mathrm{R}$ & & $\mathrm{R}$ & & $\mathrm{R}$ & & $\mathrm{R}$ \\
\hline T-test & & & T-test & & T-test & & T-test & & T-test & & T-test & & T-test & & T-test \\
\hline
\end{tabular}

N.B.: $a=$ No. of sensitive strains, $b=$ Percentage of activity. 
Table 2. In vitro determination of inhibition zone, MICs and MBCs to some representative P.multocida strains against different antimicrobial agents.

\begin{tabular}{|c|c|c|c|c|c|c|c|c|}
\hline \multirow{2}{*}{$\begin{array}{l}\text { Antimicrobial } \\
\text { agents }\end{array}$} & \multicolumn{2}{|c|}{$\begin{array}{l}\text { Inhibition zone } \\
\text { (mm) }\end{array}$} & \multicolumn{3}{|c|}{$\begin{array}{c}\text { Minimal inhibitory } \\
\text { concentration (MICs) } \mu \mathrm{g} / \mathrm{ml}\end{array}$} & \multicolumn{3}{|c|}{$\begin{array}{c}\text { Minimal bactericidal } \\
\text { concentration (MBCs) } \mu \mathrm{g}\end{array}$} \\
\hline & Range & Mean & Range & MIC50 & MIC90 & Range & MBC50 & MBC90 \\
\hline Ceftiofur sodium & $18-30$ & 24 & $0.625-2.5$ & 0.625 & 1.25 & $0.625-2.5$ & 1.25 & 2.5 \\
\hline Enrofloxacin & $15-28$ & 21.5 & $0.15-1.25$ & 0.31 & 1.25 & $0.31-2.5$ & 0.625 & 1.25 \\
\hline Flumequine & $10-20$ & 15 & $1.6-100$ & 12.5 & 50 & $3.1-100$ & 25 & $<100$ \\
\hline Gentamicin & $12-20$ & 16 & $0.31-2.5$ & 0.625 & 2.5 & $0.31-5$ & 1.5 & 2.5 \\
\hline Neomycin & $10-16$ & 13 & $3.1-50$ & 6.25 & 25 & $6.2-50$ & 12.5 & $<50$ \\
\hline Streptomycin & $12-26$ & 19 & $0.625-12.5$ & 16 & 3.1 & $3.1-25$ & 6.3 & 12.5 \\
\hline Ampicillin & $15-25$ & 20 & $20-160$ & 40 & 80 & $20-160$ & 80 & $<160$ \\
\hline $\mathrm{R}$ & & & & $\mathrm{R}$ & $\mathrm{R}$ & & $\mathrm{R}$ & $\mathrm{R}$ \\
\hline T-test & & & & T-test & T-test & & T-test & T-test \\
\hline
\end{tabular}

$0.625 \mu \mathrm{g} / \mathrm{ml}$ and more than $90 \%$ of the tested strains were inhibited in a concentration of $1.25 \mu \mathrm{g} / \mathrm{ml}$. Most of the tested strains were susceptible to enrofloxacin and gentamicin with MICs raning from $0.15-1.25 \mu \mathrm{g} / \mathrm{ml}$ and $0.31-2.5 \mu \mathrm{g} / \mathrm{ml}$ respectively. Moreover, MBCs was equal or two fold dilutions above MICs for ceftiofur, enrofloxacin and gentamicin. There were a correlation between MICs and inhibition zone on agar. The other antimicrobials had little inhibitory effect against $P$. multocida with MICs 90 values ten to one hundred fold higher compared to ceftiofur.

\subsection{Results of Experimental Infection and Treatment}

When the characteristic signs of the experimentally induced diseases i.e. Salmonellosis, Pasteurellosis and Coli bacillosis produced, then causative pathogens could be reisolated from such groups of birds. Two days after infection an intramuscular injection of $1 \mathrm{mg} / \mathrm{kg}$ B.wt. ceftiofur sodium gave a complete recovery of the inoculated birds of both first and second group while two birds of third group died and the remaining survived.

\subsection{Field Application of Ceftiofur Sodium (Excenel) Treatment}

The total mortality rate in first flock was 165 with a percentage of $3.3 \%$ while it was $7.9 \%$ in $2^{\text {nd }}$ flock as 395 birds died, the food conversion rate in first flock was 2.14 while it was 2.26 in $2^{\text {nd }}$ flock as its birds consumed 16.1 tons of food and gave marketd gross weight of 7113 $\mathrm{kg}$ as it was tabulated in Table 3 .

The characteristics of tested organisms were listed in Table 4.

\section{Discussion}

Ceftiofur sodium is registered as Excenel; a trade name imported drug as an antiinfectious agents. The obtained data revealed that in vitro testing of antibiotics sensitivity of different pathogens against ceftiofur sodium biodiscs in comparison with other commonly used antibiodiscs, indicated the superiority of the action of ceftiofur sodium biodiscs in vitro on the tested microorganisms as the growth of 39 strains of $E$. coli was inhibited with activity of $97.5 \%$, its activity for $S$. aureus was $93.75 \%$, for $P S$. aeruginosa it was $80 \%$, for Salmonella spp. it was $86.7 \%$ and $100 \%$ for both Proteus spp. and C. ovis respectively and $90 \%$ for $P$. multocida. Such data go in hand with those reported by authors $[2,8,23]$ who stated the efficacy of ceftiofur sodium for the control of $P$. multocida infection in chickens and animals. They were sated that, in disc diffusion test most $P$. multocida strains were highly sensitive to ceftiofur sodium with minimum inhibitory concentration (MICs) ranging between $0.625-2.5 \mu \mathrm{g} / \mathrm{ml}$ and minimal bactericidal concentration (MBCs) equal to or double fold MICs. While, MIC90 data for P. haemolytica, $P$. multocida and $H$. somnus isolated from bovine pneumonia in the USA and Canada were $0.06 \mu \mathrm{g} / \mathrm{ml}$ with 100\% susceptibility (Pharmacia and Upjohn). This difference in MIC for tested microorganisms may be attributed to the difference of the isolated strains from different animals and localites. The difference in susceptibility of tested strains to currently available antimicrobial agents has been documented by some authors $[8,19,23$ $25]$.

The inhibitory activity of ceftiofur sodium and other antimicrobial against $P$. multocida strains, expressed as minimum and maximum inhibitory concentration, most frequently occurring (model) MIC50, MIC90 (concentration that inhibited at least 90 percent of the tested strains) and inhibition zones are present in Table 2. In general, $P$. multocida strains were highly susceptible to ceftiofur, enrofloxacin and gentamicin, MIC90 ranged from 1.25 $2.5 \mu \mathrm{g} / \mathrm{ml}$. This study revealed that MBCs for ceftiofur 
Table 3. Results of treatment of the experimentally infected groups of birds with ceftiofur sodium (Excenel).

\begin{tabular}{|c|c|c|c|c|c|c|}
\hline \multicolumn{4}{|c|}{ A) Experimental infection } & \multicolumn{3}{|l|}{ B) Field application } \\
\hline Character & $1^{\text {st }}$ group & $2^{\text {nd }}$ group & $3^{\text {rd }}$ group & Parameter & $1^{\text {st }}$ flock & $2^{\text {nd }}$ flock \\
\hline Infected with: & S. gallinarum & P. multocida & E.coli & Food consumption & 17 tons & 16.1 tons \\
\hline Infective dose: & $6 \times 10^{4}$ & $10^{-4}$ & $10^{-9}$ & $\begin{array}{l}\text { Number and percentage of } \\
\text { dead birds }\end{array}$ & $165(3.3 \%)$ & $395(7.9 \%)$ \\
\hline Route of infection & $\mathrm{I} / \mathrm{P}$ & $\mathrm{I} / \mathrm{M}$ & $\mathrm{I} / \mathrm{V}$ & Marketed gross weight & $9753 \mathrm{~kg}$ & $7113 \mathrm{~kg}$ \\
\hline Therapeutic & $1 \mathrm{mg} / \mathrm{kg}$ B.wt. & $1 \mathrm{mg} / \mathrm{kg}$ B.wt. & $1 \mathrm{mg} / \mathrm{kg}$ B.wt. & Food conversion rate & 2.14 & 2.26 \\
\hline $\begin{array}{l}\text { Results of treatment: } \\
\text { a) Drinking water } \\
\text { b) I.M. injection }\end{array}$ & $\begin{array}{l}\text { Complete recovery } \\
\text { Completerecovery }\end{array}$ & $\begin{array}{l}\text { Complete recovery } \\
\text { Complete recovery }\end{array}$ & $\begin{array}{l}2 \text { birds died } \\
18 \text { birds survived } \\
\text { Complete recovery }\end{array}$ & - & - & - \\
\hline
\end{tabular}

Table 4. The characteristics of tested organisms.

\begin{tabular}{|c|c|c|}
\hline Species & Cultural features & Identification \\
\hline E. coli & $\begin{array}{l}\text { MacConkey agar: aerobic, large } 2 \text { - } 4 \mathrm{~mm} \text {, lactose } \\
\text { fermenting colonies. Blood agar: } 1 \text { - } 4 \mathrm{~mm} \text { colonies, } \\
\text { may appear mucoid and some strains are haemolytic. }\end{array}$ & $\begin{array}{l}\text { Gram negative usually motile bacilli.Most strains are } \\
\text { indole positive. Indole, methyl red, voges proskauer and } \\
\text { citrate utilization IMVC: }(++--) \text {. }\end{array}$ \\
\hline Staph aureus & $\begin{array}{l}\text { Blood and chocolate agar: aerobic, smooth, } 1-2 \mathrm{~mm} \text {, } \\
\text { golden cream coloured colonies, haemolytic } \\
\text { ( } \beta \text { haemolysis) due to production of haemolysin. } \\
\text { Mannitol salt agar used as a selective medium. Mannitol } \\
\text { is fermented giving rise to yellow colonies. }\end{array}$ & $\begin{array}{l}\text { Gram positive cocci, non motile, nonsporing and grape } \\
\text { like clusters. Positive coagulase, DNAse and catalase } \\
\text { test. Ferment glucose, maltose, lactse, sucrose and } \\
\text { mannitol. }\end{array}$ \\
\hline Ps. aeruginosa & $\begin{array}{l}\text { Blood agar: aerobic, large, flat and haemolytic colonies. } \\
\text { Most strains produce pyocyanin and fluorescein } \\
\text { pigment (green-yellow in medium). MacConkey agar: } \\
\text { non-lactose fermenting colonies with yellow-green in } \\
\text { medium. TSI: pink-red slope and butt. }\end{array}$ & $\begin{array}{l}\text { Gram negative motile bacilli. Rapidiy positive oxidase } \\
\text { and catalase test. Indole is not produced and liquefy } \\
\text { gelatin. }\end{array}$ \\
\hline Salmonella species & $\begin{array}{l}\text { XLD (xylose lysine deoxycholate) agar: aerobic, } \\
\text { pink-red colonies with black centers. Selenite broth is } \\
\text { used as enrichment medium. } \\
\text { MacConkey agar, DCA, SS agar: colourless non lactose } \\
\text { fermenter colonies TSI: pink-red slope and yellow butt. }\end{array}$ & $\begin{array}{l}\text { Gram negative short bacilli. Non sporing and motile } \\
\text { except } S \text {. gallinarum non motile. Indole, V.P., urease } \\
\text { and oxidase are negative. Citrate, catalase, } \mathrm{H}_{2} \mathrm{~S} \text { and MR } \\
\text { are positive. }\end{array}$ \\
\hline Proteus species & $\begin{array}{l}\text { MacConkey agar: aerobic, non lactose fermenting pale } \\
\text { yellow swarming colonies. Blood agar: produce } \\
\text { swarming colonies. }\end{array}$ & $\begin{array}{l}\text { Gram negative bacilli. Non sporing and motile. Urease, } \\
\text { gelatin liquefaction and indole are positive. Oxidase test } \\
\text { negative. }\end{array}$ \\
\hline Pasteurella multocida & $\begin{array}{l}\text { Blood agar: aerobic, non haemolytic, Smooth, rough or } \\
\text { mucoid colonies. MacConkey agar: no growth as the } \\
\text { bile inhibits its growth. }\end{array}$ & $\begin{array}{l}\text { Gram negative coccobacilli with bipolar staining, non } \\
\text { sporing, non motile and capsulated. Oxidase }(+) \text {, } \\
\text { ferment sucrose with acid production only, catalase and } \\
\text { indole positive. Urease, } \mathrm{H}_{2} \mathrm{~S} \text { and gelatin are negative. }\end{array}$ \\
\hline Corynebacterium bovis & $\begin{array}{l}\text { Blood agar: aerobic, colonies surrounded by narrow } \\
\text { zone of haemolysis. Loeffler's serum give small } \\
\text { yellowish white colonies. }\end{array}$ & $\begin{array}{l}\text { Gram positive pleomorphic with palisade and Chinese } \\
\text { letter-like arrangement. Ferment glucose and maltose } \\
\text { without gas formation. Catalase and urease tests are } \\
\text { positive. }\end{array}$ \\
\hline
\end{tabular}

was nearly similar to its MICs against most tested strains strongly suggested that ceftiofur exerts bactericidal effect. This results confirmed the findings of most authors $[1,13,19,25-27]$. They reported that ceftiofur sodium exerts bactericidal effect on tested microorganisms at concentration equal to or at most one doubling dilution above MIC. Many authors were reportedthat high activity of ceftiofur against $P$. multocida isolated from cattle, swine and duck in vitro $[10,12,28,29]$. Also, some authors [8] reported that the MIC of ceftiofur sodium required to inhibit growth of $90 \%$ of isolates of E. coli, Pasteurella spp., Klebsiella spp., and beta-haemolytic
Streptococci was $<0.5 \mathrm{microg} / \mathrm{ml}$, and intravenous administration of ceftiofur sodium at rate of $5 \mathrm{mg} / \mathrm{kg}$ every $12 \mathrm{~h}$ would provide sufficient coverage for the treatment of susceptible bacterial isolates. The present data for ceftiofur sodium confirm this activity. Ceftiofur sodium was superior to many other $\beta$-lactamase group with respect to its activity against wide range of Gram-positive and Gram-negative organisms, specially $\beta$-lactmase producing strains. Moreover, ceftiofur was converted to dysfuroy1 ceftiofur in serum almost instantly. Dysfuroyl ceftiofur was comparable in potency to ceftiofur against different organisms and P. multocida [30]. Mean serum 
concentration of ceftiofur and its metabolites peaked approximately one hour after each injection and the highest mean concentration was $5.09 \mu \mathrm{g} / \mathrm{ml}$. This concentration was five to ten fold above MIC of most tested organisms [6]. The ability of ceftiofur to reduce mortality rate was therefore considerable. The efficacy of ceftiofur was also evident by improved mean body weight gain, feed intake and feed conversion. The improvement of the body gain in response to treatment with ceftiofur is most likely imputable to a proposed improvement of the general health of birds, increase feed intake and increase absorption of nutrients. This previous assumption was supported by some authors [1,19,31]; whose reported that after the lapse of the acute phase of the infection, the drugs improve weight gain in consequence of an increased feed intake and increased absorption of nutrients.

Statistical analysis of results were done and recorded as in Tables 1 and 2, which revealed that a significant difference between different parameters $(\mathrm{P}>0.05)$.

\section{Conclusion}

The obtained results revealed that ceftiofur sodium (Excenel) was more effective and superior in its action than the other compared antibacterial agents. Ceftiofur sodium (Excenel) is a chemotherapeutic effective agent for uses in veterinary practice as it action was confirmed both in vitro and either in artificially infected or in naturally reared birds.

\section{REFERENCES}

[1] R. E. Hornish and S. F. Kotarski, "Cephalosporions in Veterinary Medicine-Ceftiofur Use in Food Animals," Current Topics in Medicinal Chemistry, Vol. 2, No. 7, 2002, pp. 717-731. doi:10.2174/1568026023393679

[2] A. E. Abd-Ellateif and I. M. G. El-Din, "The Role of Ceftiofur Sodium (Excenel) in the Control of Pasteurella multocida Infection in Chickens," Proceeding of the 4th Veterinary Medicine Zagazing Congress, Hurghada, 2628 August 1998, pp. 632-645.

[3] A. M. Fayaz, K. Balaji, M. Girilal, R. Yadav, P. T. Kalaichelvan and R. Venketesan, "Biogenic Synthesis of Silver Nanoparticles and Their Synergestic Effect with Antibiotics: A Study against Gram Positive and Gram Negative Bacteria," Nanomedicine: Nanotechnology, Biology and Medicine, Vol. 6, No. 1, 2010, pp. 103-109. doi:10.1016/j.nano.2009.04.006

[4] R. J. Yancey, M. Kinney, B. Roberts, K. Goodenough, J. Hamel and C. Ford, "Ceftiofur Sodium a Broad Spectrum Cephalosporin: Evaluation in Vitro in Mice," American Journal of Veterinary Research, Vol. 48, No. 7, 1987, pp. 1050-1053.

[5] X. L. Li, M. Weizhen, L. Michael, Y. Machesk, S. R. Yates and M. Katterhenry, "Degradation Kinetics and Mechanism of Antibiotic Ceftiofur in Recycled Water Derived from a Beef Farm," Journal of Agricultural and
Food Chemistry, Vol. 59, No. 18, 2011, pp. 10176-10181. doi:10.1021/jf202325c

[6] S. A. Brown, P. S. Jaglan and A. Banting, "Ceftiofur Sodium, Disposition, Protein-Binding, Metabolism, Small Residue Depletion Profile in Various Species," Acta Veterinaria Scandinavica Supplementum, Vol. 86, 1991, p. 99.

[7] S. A. Salmon, J. L. Watts and R. J. Yancey, "In Vitro Activity of Ceftiofur and Its Metabolites Desfuroyl Ceftiofur against Organism of Veterinary Importance," Journal of Veterinary Diagnostic Investigation, Vol. 8, No. 3, 1996, pp. 332-336. doi:10.1177/104063879600800309

[8] S. Meyer, S. Giguere, R. Rodriguez, R. J. Zielinski, G. S. Grover and S. A. Brown, "Pharmacokinetics of Intravenous Ceftiofur Sodium and Concentration in Body Fluids of Foals," Journal of Veterinary Pharmacology and Therapeutics, Vol. 32, No. 4, 2009, pp. 309-316. doi:10.1111/j.1365-2885.2008.01041.x

[9] T. L. Hall, L. A. Tell, S. E. Wetzlich, J. D. McCormick, L. W. Fowler and N. Pusteria, "Pharmacokinetics of Ceftiofur Sodium and Ceftiofur Crystalline Free Acids in Neonatal foalsm," Journal of Veterinary Pharmacology and Therapeutics, Vol. 34, No. 4, 2011, pp. 403-409. doi:10.1111/j.1365-2885.2010.01252.x

[10] E. J. C. Goldstein, D. M. Goldstein, C. V. Merriam and K. L. Tyrrell, "Ceftaroline versus Isolates from Animal Bite Wounds: Comparative in Vitro Activities against 243 Isolates, Including 156 Pasteurellaspecies Isolates," Antimicrobial Agents and Chemotherapy, Vol. 56, No. 12, 2012, pp. 6319-6323. doi:10.1128/AAC.01794-12

[11] T. R. Schriemer, J. B. Paulissen and K. J. Dame, "Evaluation of Ceftiofur Sodium for Control of Terminal Bacterial Infection in One Day Old Broiler Chickens," Proceeding of the 19th World Poultry Congress, Ilege, 19-24 September 1992, pp. 11-15.

[12] K. L. Hope, L. A. Tell, B. A. Byrne, S. Murray, S. E. Wetzlich, L. H. Ware, W. Lynch, L. R. Padilla and N. C. Boedeker, "Pharmacokinetics of a Single Intramuscular Injection of Ceftiofur Crystalline-Free Acid in American Black Ducks (Anasrubripes)," American Journal of Veterinary Research, Vol. 73, No. 5, 2012, pp. 620-627. doi:10.2460/ajvr.73.5.620

[13] R. S. Singer, S. K. Patterson and R. L. Wallace, "Effects of Therapeutic Ceftiofur Administration to Dairy Cattle on E. coli Dynamics in the Intestinal Tract," Applied and Environmental Microbiology, Vol. 74, No. 22, 2008, pp. 6956-6962. doi:10.1128/AEM.01241-08

[14] S. M. Finegold and W. J. Martin, "Diagnostic Microbiology," 6th Edition, C.V. Mosby Co. St. Louis, Toronto, London, 1982.

[15] J. Gangoue-Pieboji, N. Eze, D. A. Ngongang, B. Ngameni, N. Tsabang, D. E. Pegnyemb, L. Biyiti, P. Ngassam, S. S. Koulla and M. Galleni, "The in-Vitro Antimicrobial Activity of Some Medicinal Plants against Beta Lactam Resistant Bacteria," Journal of Infection in Developing Countries, Vol. 3, No. 9, 2009, pp. 671-680.

[16] J. G. Choi, O. H. Kang, Y. S. Lee, H. S. Chae, Y. C. Oh, O. O. Brice, M. S. Kim, D. H. Sohn, H. Sookim, H. Park, D. W. Shin, J. R. Rho and D. Y. Kwon, "In Vitro and in 
Vivo Antibacterial Activity of Punicagranatum Peel Ethanol Extract against Salmonella," Evidence-Based Complementary and Alternative Medicine, Vol. 211, No. 1, 2011, p. 8.

[17] P. I. Ushimaru, L. N. Barbosa, A. A. H. Fernandes, L. C. Distasi and A. F. Junior, "In Vitro Antibacterial Activity of Medicinal Plant Extracts against Escherichia coli Strains from Human Clinical Specimens and Interactions with Antimicrobial Drugs," Natural Product Research, Vol. 26, No. 16, 2012, pp. 1553-1557. doi:10.1080/14786419.2011.568943

[18] Anon, National Committee for Clinical Laboratory Standards, "Method for Dilution Antimicrobial Susceptibility Tests for Bacteria That Grow Aerobically," 2nd Edition, Document M7A2 (NCCLS), Vol. 10, 1991, pp. 1-13.

[19] L. Dutil, R. Irwin, R. Finley, K. Ngl and B. Avery, "Ceftiofur Resistance in Salmonella entericserovar Heidelbery from Chicken Meat and Humans, Canada," Emerging Infectious Diseases, Vol. 16, No. 1, 2010, pp. 48-54. doi:10.3201/eid1601.090729

[20] T. G. Hungerford, "A Clinical Rate on Avian Cholera; The Effect of Age on the Susceptibility of Fowls," Australian Veterinary Journal, Vol. 44, No. 1, 1968, pp. 3132. doi:10.1111/j.1751-0813.1968.tb04912.x

[21] W. B. Gross and C. H. Domermuth, "Colibacillosis; In Isolation and Identification of Avian Pathogens," 2nd Edition, Creative Prin. Co., New York, 1980.

[22] M. Scheer, "Studies on the Antibacterial Activity of Baytril (Enrofloxacin)," Veterinary Medical Review, Vol. 2, No. 1, 1987, pp. 90-99.

[23] D. L. Raemdanek, A. C. Tanner, S. T. Tolling and S. L. Michener, "In Vitro Susceptibility of Avian Escherichia coli and Pasteurella multocida to Danofloxacin and Five Other Antimicrobials," Avian Diseases, Vol. 36, No. 4,
1992, pp. 694-697.

[24] D. Persons, F. Haesebrouck, A. Smet, L. Herman and M. Heyndrickx, "Risk Factors for Ceftiofur Resistance in Escherichia coli from Belgian Broilers," Epidemiology and Infection, Vol. 139, No. 5, 2011, pp. 765-771. doi:10.1017/S0950268810001524

[25] A. Franklin, "The in Vitro Bactericidal Activity of Danofloxacin and Ceftiofur against Respiratory Pathogens in Cattle," Proceedings of the 17th world Buiatrics Congress, Vol. 3, 1992, pp. 214-217.

[26] L. K. Klein, R. J. Yancey, C. A. Case and S. A. Salmon, "Minimum Inhibitory Concentration of Selected Antimicrobial Agents against Bacteria Isolated from 1 - 14 Day Old Broiler Chicks," Journal of Veterinary Diagnostic Investigation, Vol. 8, No. 4, 1996, pp. 494-495. doi: $10.1177 / 104063879600800418$

[27] H. Hariharan, E. Croft, S. Heaney and Y. Bryenton, "Drug Resistance Patterns among Salmonella Isolates," The Canadian Veterinary Journal, Vol. 34, No. 12, 1993, pp. 45-47.

[28] P. J. Blackall, J. Pahoff, C. P. Stephens and F. M. Darvill, "In Vitro Activity of Ceftiofur against Pasteurella Isolates of the Family Pasteurellacea Associated with Respiratory Disease in Cattle and Pigs. Aust," The Veterinary Journal, Vol. 74, No. 1, 1996, p. 71.

[29] S. A. Brown, R. J. Yancey and J. Steffan, "Ceftiofur Sodium: Antimicrobial Activity of Parent Ceftiofur and Metabolites," Acta Veterinaria Scandinavica Supplementum, Vol. 87, No. 1, 1991, p. 95.

[30] F. Alexander, "An Introduction of Vet. Pharm," 4th Edition, Longman, London, New York, 1985.

[31] W. C. Scheffer, "Statistics for Biological Sciences," 2nd Edition, Addison Wesley, Reading, 1979. 